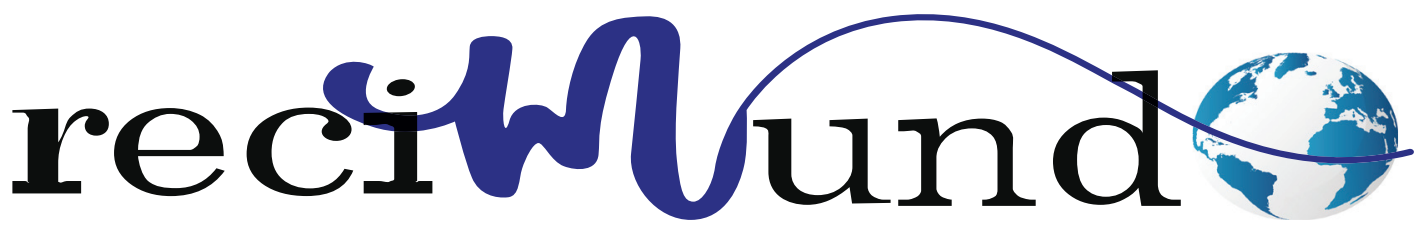

Revista Científica Mundo de la Investigación y el Conocimiento

DOl: 10.26820/recimundo/4.(1).enero.2020.379-389

URL: http://recimundo.com/index.php/es/article/view/767

EDITORIAL: Saberes del Conocimiento

REVISTA: RECIMUNDO

ISSN: 2588-073X

TIPO DE INVESTIGACIÓN: Artículo de Revisión

CóDIGO UNESCO: 5801 Teoría y Métodos Educativos;

5801.04 Teorías Educativas

PAGINAS: 379-389

\title{
Innovation strategies in the grammar teaching of English and its effectiveness during the third level educational process
}

Estrategias de innovación en la enseñanza de la gramática del inglés y su efectividad durante el proceso educativo de tercer nivel

Estratégias de inovação no ensino de gramática do inglês e sua eficácia durante o processo educacional de terceiro nível

Veliz Blacio Jacqueline Jeaneen ${ }^{1}$

RECIBIDO: 18/09/2019 ACEPTADO: 29/10/2019 PUBLICADO: 31/01/2020

1. Licenciada en Lengua Inglesa, Graduada en la Universidad Católica de Guayaquil; Docente de la Universidad de Guayaquil; Certificada Academia Internacional en la Niveles C1 y B2; Graduada y Titulada en Academias de Inglés Centro Ecuator; Universidad de Guayaquil; Guayaquil, Ecuador; jeaneenveliz94@hotmail.com; (D) https://orcid.org/0000-0002-00713399

CORRESPONDENCIA

Veliz Blacio Jacqueline Jeaneen

jeaneenveliz94@hotmail.com

Guayaquil, Ecuador

(c) RECIMUNDO; Editorial Saberes del Conocimiento, 2020 


\section{RESUMEN}

El dominio del inglés es una habilidad de creciente importancia competitiva para el desarrollo profesional, por lo que su aprendizaje efectivo en la preparación universitaria tiene un carácter estratégico. El bajo nivel de dominio de este idioma en la escala nacional y regional, constituye un importante indicador de la poca efectividad de los métodos y estrategias aplicadas en el sistema educativo ecuatoriano, en este contexto la presente investigación de tipo documental tiene como propósito realizar una revisión de las diversas estrategias educativas y evaluativas en el aprendizaje de esta segunda lengua, valorando su utilidad y efectividad, y contribuyendo de esta forma al debate para revertir esta situación.

Palabras clave: Evaluación, Aprendizaje Efectivo, Estrategias Educativas.

\section{ABSTRACT}

Proficiency in English is a skill of increasing competitive importance for professional development; therefore effective learning in university preparation has a strategic character. The low level of mastery of this language at the national and regional level, constitutes an important indicator of the poor methodology and strategies applied in the Ecuadorian education system, in this context the present investigation of documentary type is intended to conduct a review of the various educational and evaluative strategies in learning this second language, assessing its usefulness, and thus contributing to the debate to reverse this situation.

Keywords: Evaluation, Effective Learning, Educational Strategies.

\section{RESUMO}

Proficiência em inglês é uma habilidade de crescente importância competitiva para o desenvolvimento profissional; portanto, a aprendizagem eficaz na preparação da universidade tem um caráter estratégico. O baixo nível de domínio dessa língua nos níveis nacional e regional constitui um importante indicador da péssima metodologia e das estratégias aplicadas no sistema educacional equatoriano. Nesse contexto, a presente investigação do tipo documental visa realizar uma revisão das várias estratégias educacionais e avaliativas na aprendizagem deste segundo idioma, avaliando sua utilidade e, assim, contribuindo para o debate para reverter essa situação.

Palavras-chave: Avaliação, Aprendizado Efetivo, Estratégias Educacionais. 


\section{Introduction}

In the context of a globalized world, interconnected through information and communication technologies, mediated by business patterns and organizations of North American and English origin, learning the English language has become an essential tool for professional performance, being also a sine qua non determinant requirement to achieve optimum levels of international competitiveness at the economic and professional level. In this sense, the integration of courses and training components associated with the management of this language is increasingly common in the curricular structures of the academic programs in universities and is even compulsory in some Latin American countries. .

However, despite the massive studies of this language at all educational levels, the results are not in all cases the expected, since particularly in Latin America there are only few countries where the population in general, and the youth population in particular, they have a basic command of the language.
Multiplicity of strategies can be found in reference to the effective learning of this important language, from the traditional ones to those where computer, audiovisual and technological interaction tools are used, however there are still important limitations in the established educational systems that could affect the professional capacity of university students and even national development skills because of a low management of a language that has become the main communication language worldwide.

\section{The problem of low English proficiency in Ecuador}

According to the 2019 report of the Education First (EF) agency, Ecuador was ranked No. 81 on a list of 100 countries where tests were conducted, obtaining a score of 46.57 in the measurement of the English Proficiency Index, indicator prepared by this agency, where the acquisition of English skills of fuII-time students between 13 and 22 years is examined. Within the Latin American countries Ecuador occupied the lowest place, with the position $\mathrm{N}^{\circ} 19$ of the 19 Latin American countries where the index was measured. (Education First, 2019)

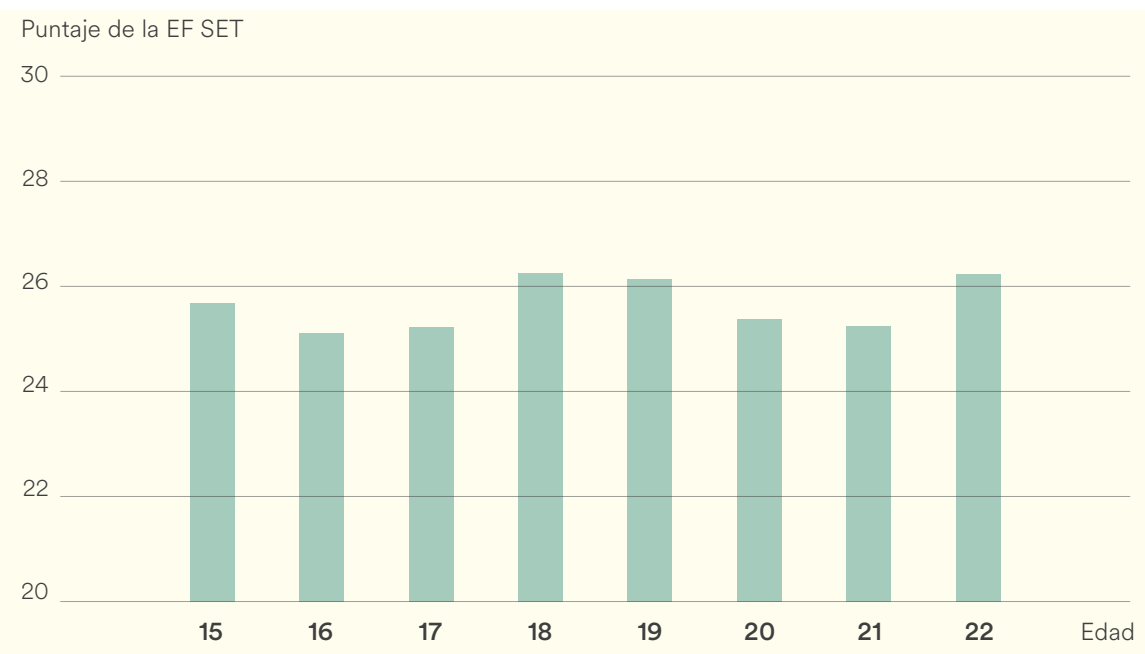

Gráfica 1. Dominio del inglés por edades

Fuente: (Education First, 2019) 
The EF Report reveals that in terms of trend, there has been a decrease in the country's progress in terms of handling English, going from occupying a low grade (35/63) in 2014 to occupying a very low position $(81 / 100)$ in 2019.

\section{Tendencias del EF EPI}

\begin{tabular}{|c|c|c|c|c|c|}
\hline 2014 & 2015 & 2016 & 2017 & 2018 & 2019 \\
\hline 163 & & & & & 78 \\
\hline - Bajo & - Bajc & Bajo & Bajc & - Baj & Muy bajo \\
\hline
\end{tabular}

Gráfica 2. Trend of the EP EPI 2014-2019

Fuente: (Education First, 2019)

These data reflect a series of deficiencies from multiple sources, some of which are associated with the poor management of teaching strategies and techniques, as well as evaluation strategies that could allow a balanced and comprehensive assessment of learning, within the framework of an effective teaching method.

Some authors stand out among the many factors that interfere with an effective teaching of the language "The limited number of hours available for the exercise of skills tends to produce a considerable deficiency in the process of skills development. Each of these skills needs specific strategies to be addressed and the objectives set for it are almost never fully developed successfully. Likewise, the tasks entrusted by the teacher (which are carried out inside or outside the classroom), are generally relegated to a quick review, because there is not enough time to give the student an adequate correction of errors " (Morales \& Ferreira, 2008)

Other factors that impact learning have to do with high levels of anxiety, the inconsistent and unplanned use of educational strategies, particularly social strategies and cognitive goals, as well as a low level of motivational intensity and a poor evaluation of the course and / or of the teacher, are factors that prevent an optimal learning of English as a foreign language. Social factors, such as the socio-economic stratum from which a student comes, may be an element that does not favor the learning of a foreign language. (Diaz Mejia, 2014)

Within the framework of this problem, the present work proposes to review from a documentary perspective, different strategies of effective evaluation in the learning of English in university preparation, in order to contribute to the debate on the necessary improvement of language proficiency levels in the national scale

\section{Methodology}

The present investigation is documentary type, since the review of evaluative strategies of English language learning is based on scientific articles, reports and other publications that were accessed. Documentary research is defined by Fidias Arias as:

"... A process based on the search, recovery, analysis, criticism and interpretation of secondary data, that is, those obtained and registered by other researchers in documentary sources: printed, audiovisual or electronic. As in all research, the purpose of this design is the contribution of new knowledge. " (Arias, 2012)

Prior to addressing the different strategies for effective evaluation of the English language, it is necessary to define the meaning of the concepts of evaluation and effective learning, on which the present analysis is 


\section{INNOVATION STRATEGIES IN THE GRAMMAR TEACHING OF ENGLISH AND ITS EFFECTIVENESS DURING THE THIRD LEVEL EDUCATIONAL PROCESS}

based. Below is a table where you can see the educational field. various concepts of evaluation applied to

Tabla 1. Evaluation concepts

\begin{tabular}{|c|c|}
\hline AUTHOR & DEFINITION \\
\hline ronlund (1973) & $\begin{array}{l}\text { Systematic process to determine the extent of the student achievement towards } \\
\text { the objectives of education. }\end{array}$ \\
\hline Mager & $\begin{array}{l}\text { Process to determine the degree or extent of some characteristic associated } \\
\text { with an object or a person. }\end{array}$ \\
\hline $\begin{array}{l}\text { De La Orden } \\
\text { (1981) }\end{array}$ & $\begin{array}{l}\text { Process of collecting and analyzing relevant information to describe any facet } \\
\text { of the educational reality and formulate a judgment on its adequacy to a pattern } \\
\text { or criteria previously established as the basis for decision making. }\end{array}$ \\
\hline afour & $\begin{array}{l}\text { Stage of the educational process that aims to systematically verify the extent to } \\
\text { which the expected results have been achieved in the objectives specified in } \\
\text { advance. }\end{array}$ \\
\hline $\begin{array}{l}\text { García Ramos } \\
\text { (1994) }\end{array}$ & $\begin{array}{l}\text { Systematic process of identification, collection and treatment of data on } \\
\text { educational elements and facts with the objective of assessing them first, and } \\
\text { on from that evaluation, making decisions. }\end{array}$ \\
\hline $\begin{array}{l}\text { Rodríguez } \\
\text { Diéguez (1998) }\end{array}$ & $\begin{array}{l}\text { Process of collecting information about a student or a class group in order to } \\
\text { make decisions that affect teaching situations }\end{array}$ \\
\hline Zabalza & $\begin{array}{l}\text { Process that involves at least the following phases: (a) collection of information, } \\
\text { (b) assessment of the information collected, and (c) decision making. }\end{array}$ \\
\hline $\begin{array}{l}\text { Castillo Arredondo } \\
\text { y Cabrerizo Diego } \\
\text { (2003) }\end{array}$ & Dynamic, open and contextualized process that develops over a period of time. \\
\hline $\begin{array}{l}\text { Rodríguez Conde } \\
\text { (2005) }\end{array}$ & $\begin{array}{l}\text { Set of systematic processes of collection, analysis and interpretation of valid } \\
\text { and reliable information, which in comparison with a reference or criterion } \\
\text { allows us to reach a decision that favors the improvement of the object } \\
\text { evaluated. }\end{array}$ \\
\hline $\begin{array}{l}\text { De Miguel Díaz } \\
\text { (2006) }\end{array}$ & $\begin{array}{l}\text { A planned, comprehensive and relevant process to the competences that are } \\
\text { desired to be achieved. It is developed through the approach of tasks or } \\
\text { challenges that the student must solve, needing an integrated set of } \\
\text { knowledge, skills and attitudes. }\end{array}$ \\
\hline $\begin{array}{l}\text { Díaz Barriga } \\
(2006)\end{array}$ & $\begin{array}{l}\text { Process by which the student demonstrates certain behaviors or skills in } \\
\text { context. For this, the teacher must use a varied range of evaluation strategies, } \\
\text { which allow him to obtain evidence of the performance of the competition. }\end{array}$ \\
\hline Cano (2008) & $\begin{array}{l}\text { A process that uses a variety of instruments and involves different agents, with } \\
\text { the purpose of providing information on the progression in the development of } \\
\text { the competition and suggest ways of improvement. }\end{array}$ \\
\hline
\end{tabular}

Fuente: (Ruiz Morales, 2014) 
In the concepts presented, in an evident evolution whose result is the recognition of the existence of a diversity of evaluation strategies, as can be read in the definitions of Díaz Barriga and Cano. Certainly the integration of technologies in the learning processes, as well as the transformation in educational trends, have allowed the combination of different evaluation tools and with this an evolution in the traditional knowledge exchange schemes and ways of understanding the evaluation process.

In the particular case of effective teaching, it implies the ability to provide instruction that helps students develop the knowledge, skills and understandings provided by curricular objectives, creating a climate of instruction that causes students to develop positive attitudes towards school and to themselves, adjust instruction so that all students learn, regardless of ability, ethnicity, or other characteristics, administer the classroom so that students participate in learning, all or most of the time, make decisions and solid plans that maximize student learning opportunities and respond to initiatives for curriculum change so that the intentions of the new curriculum are fully realized (Acheson, 2003).

Within the effective teaching approach, the adaptability and versatility of the instruction stand out according to the characteristics of the students, so there is greater flexibility in the learning process, since their particular conditions are taken into consideration.

\section{English teaching methods and strategies in the learning assessment}

Multiple methods of teaching English can be found in the bibliography, an exhibition of some of them will be held here, hoping to contribute to the search for best practices in the teaching process of this important language.

It is necessary to understand that every evaluation strategy is closely related to the teaching methods of the second language
(L2), so that the evaluation process must be understood as an integrated part of the integral learning process. The main teaching methods of $\mathrm{L} 2$ that are commonly applied are described by Morales and Ferreira, these are: task-based language learning and cooperative learning, each of which has implicit evaluation methods associated with their philosophy.

In the case of task-based language teaching "language is never an object of study but a communication tool to execute tasks (real-life or with specific pedagogical purposes) that provides a better context for the activation of cognitive processes in the second language learning, which require negotiation of meaning in a natural communication, with real significance for students. These tasks are sequenced according to their difficulty, which depends on the students' previous experience, the complexity of the task, the level of support available or the linguistic elements necessary to perform them. " (Morales \& Ferreira, 2008)

On the other hand, cooperative learning is the antithesis of competitive learning. Emphasize cooperative planned and highly interactive, student-centered activities. Each student is responsible for their own learning and is motivated to encourage the learning of others through the socially structured exchange of information between pairs of students and small groups ... Each student must learn to plan, monitor and evaluate their learning, which requires active and direct participation. The teacher's role is to facilitate learning, responsible for creating a highly structured and organized environment, setting goals, planning and structuring tasks, defining the physical distribution of the elements in the room, determining the groups of students and their roles, selecting the materials and allocate adequate time to complete the task. The collaboration in the classroom begins with an activity that facilitates real communication (verbal, written or electronic discussion) to solve a problem. (Morales \& Ferreira, 2008) 


\section{INNOVATION STRATEGIES IN THE GRAMMAR TEACHING OF ENGLISH AND ITS EFFECTIVENESS DURING THE THIRD LEVEL EDUCATIONAL PROCESS}

As you can see the evaluation strategies in these models are focused on the ability to perform the task and in the other the student participates in the monitoring and planning of their process while interacting with other students.

Deepening the methods of learning the second language, other authors provide an evolutionary review of methodological approaches in the teaching of English, (BaIlestero \& Batista, 2007), which stand out:

- In 1930 the initial influence of structuralism is evidenced, with De Saussure's approaches, which would later be expanded with the influence of behavioral psychology, leading to a behavioral theory of learning where language knowledge is mediated through a mechanical process of fixing habits, grammatical guidelines and vocabulary.

- In 1956 Chomsky states that linguistic patterns arise from knowledge acquired thanks to individuals having an innate form of a language acquisition device, which facilitates the learning of any language, resulting in communicative execution.

- In 1969, the Harris language proficiency model appears where language proficiency is assessed based on the skills demonstrated in speech, writing, reading, phonology, grammar and fluency. This based on audio-lingual methodology, focusing attention on structure and repetition, where context and meaning are not the most relevant.

- In 1980 Canale and Swain resume Chomsky's concept of communicative execution, and incorporate sociolinguistic, strategic and conversational skills complementing this approach. Krashen (1981) nurtures this model by adding the concept of understandable information input and the monitor, as essential elements of learning. Other authors such as Cummins (1979) add to that theory other elements such as the interdependence between the native language and the second language, the basic skills for interpersonal communication (BICS) and the cognitive and academic proficiency of the language. The Cummins model highlights the importance of context in the learning and compression process, leading to a cognitive theory of learning.

- In 1990 Bley-Vroman and White made contributions within the framework of the constructivist perspective of learning, stating that the student takes the information and processes it in a unique way according to their needs, dispositions, attitudes, beliefs, feelings and finally, one of the most important factors: previous experience... According to these approaches, learning a language is constructed in a more subjective way, taking into account the affective factor of motivation which is related to the goal of cognition. (Ballestero \& Batista, 2007)

Another necessary element to consider is the incorporation of Communication and Information Technologies in the evaluation of learning, in this sense Ruiz Morales referring to Barbera (2006) highlights three major changes achieved thanks to these: automatic evaluation, encyclopedic evaluation and collaborative evaluation. The first one consists of a series of electronic assessments under the test format, which allows the student to interact with a series of questions that, when selected and answered, offer immediate feedback. The second one is based on the elaboration of written works of documentary type in the second language language with support in the resources and sources of virtual information, while the third one consists in carrying out exchange activities such as forums, debates and other interaction spaces (Ruiz Morales, 2014).

On the other hand Martínez (2013), after conducting a review of various evaluation modalities, concludes that the main methods used for the evaluation of autonomous

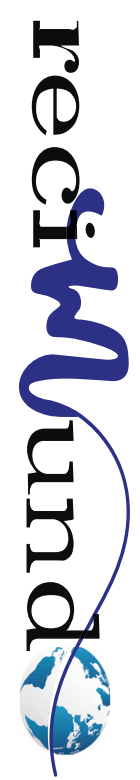


learning of foreign languages are:

- Preparation of the student portfolio. It can be in different ways: in student diaries, exercises, open activities, among others.

- Discussion in pairs or in groups on a topic provided by the tutor or selected by the students. It can be done in different ways: in forum, in wiki, in web log, among others.

- Online exams for students to take in their free time. It could be develop in different ways: questionnaires, tasks, the lesson, among others.

- Evaluation in pairs, in groups and self-evaluation. It can be developed in the workshop.

- Oral presentations. They can be developed in different ways: in face-to-face consultations with an advisor (if necessary), recorded in audio format or video format (in both formats the tools and training for their use is guaranteed) and uploading it to the course through the task as an activity (Martinez, Martinez, \& Lopez, 2013)

These same authors assume the concept of autonomous language learning, describing it as the one in which the student develops skills such as time management, need for analysis, activity planning, assessment of the activities carried out, reorientation, monitoring and commitment to the integrality of the learning process, so it is part of the Meta cognitive perspective.

It is interesting to summarize the dimensions of the evaluation provided by the aforementioned authors, after an exhaustive review of the literature, they highlight: meta cognitive, which consists of a type of intelligence that favors the development of self-regulation skills and decisions making; the cognitive one based on the verification of knowledge, skills and values and the emotional partner, where feelings, emotions, interests are con- sidered, which stimulate motivation in order to guarantee the fulfillment of the objectives. Finally, they point out the importance of the procedural-autonomous dimension, which consists in the performance based on decision-making that evidences knowledge of the methods, procedures, techniques and indicators by which the evaluation will be carried out, as well as the level of autonomy that it has for Make use of them. (Martinez, Martinez, \& Lopez, 2013)

Regarding the strategies that determine the usefulness of the evaluation for the student, they recommend applying the following:

- Motivation.

- Creation of learning activities.

- Feedback to the student, identifying strengths and weaknesses.

- Feedback to the facilitator and study group on how the learning process develops.

- Offer performance ratings.

- Quality assurance, both internal and external to the institution. (Martinez, Martinez, \& Lopez, 2013)

Other authors such as Madrid, C., highlight the objectivity of the strategy called TEST in language learning, first defining the TEST as the one used to measure certain capacities, skills and abilities, conceptual aspects or attitudes and values of the apprentices. (Madrid, 1997)

Madrid in reference to other authors deepens the definition of the test as a measuring instrument designed to provide data (information) on the behavior of the subjects with respect to certain competences. What distinguishes the tests from other types of measurement is that they are designed to obtain specific samples on certain subject competencies. (Madrid, 1997)

Additionally, Madrid collects the different types of tests that can be found for the as- 
sessment of English proficiency, which we summarize below:

- Proficiency test: these measure the aptitude of the students for the learning of the second language. The two most commonly used proficiency tests are the Elementary Modern Language Aptitude, which considers ability to code and store sounds, grammar ability, memorization of linguistic elements and inductive ability to learn languages; and the Test Language Aptitude Battery that measures verbal intelligence, auditory ability, motivation and verbal intelligence through vocabulary.

- Performance and progress test: they measure the learning acquired by the student in a specific period of instruction, this allows monitoring their progress.

- Diagnostic and level test: they serve to identify the level of students' previous competence, weaknesses and strengths in linguistic aspects.

- Standardized level tests: which measure linguistic and communication skills based on parameters and requirements established by institutions and organizations of international scope, beyond the learning source of those participating in the test. The main tests of this type are: Preliminary English Test (PET), Cambridge First Certificate (CFC), Comprenhensive English Language Test for Speakers of English as a Second Language (CELT), Oxford Proficiency Test, MLA Proficiency Tests for Teachers and Advanced Students, Test of English as a Foreign Language (TOEFL). (Madrid, 1997)

For the purposes of university preparation, these last types of tests establish an evaluation standard for professionals, since their approval is a common requirement in companies, as well as are required to apply for positions in international organizations or access study programs in institutions whe- re proven language proficiency is required. In this sense, university preparation should consider these standards when designing curricular structures, especially in those disciplines where the management of this second language is vital for the updating of knowledge, techniques and technologies.

One of the elements that we can highlight when carrying out a review of the different strategies and methods described, is the importance of individual and personal motivation to achieve the learning objectives, therefore the evaluation schemes have been transforming towards an autonomous learning vision, transcending old punitive evaluation schemes.

One of the evaluative and self-evaluating instruments that fits into the perspective, where students are the protagonist and self-regulatory of their learning process is the portfolio. Lunar presents a valuable description of the usefulness of the portfolio as a strategy to evaluate the English written production by university students. The Portfolio is described as a strategy that allows compiling the information that the student generates in each session and content addressed during their learning process, making it a powerful co-evaluative and self-evaluative tool.

The study carried out by Lunar regarding the portfolio allowed him to demonstrate the usefulness, flexibility and versatility of the portfolio as an evaluation strategy since it integrates different types of evaluation (co-evaluation, self-evaluation) and activities (preparation of the learning logbook, portfolio design, self-monitoring and exercise of reflection processes to promote student self-awareness)(Lunar, 2007).

\section{Conclusions}

As it could be observed, there are various methods and strategies available today to facilitate effective learning of English, this diversification is related to the influence of the different schools of thought, from structuralism, through behaviorism, constructi-

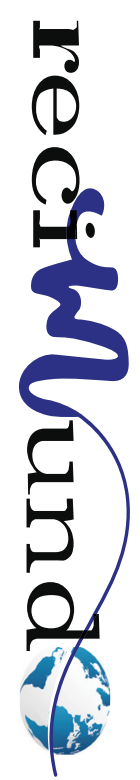


vism and approaches that integrate incorporation of technologies in the evaluation and didactics of learning.

Reversing the decreasing results in English proficiency implies assuming new teaching methods and strategies in the curricular designs of national universities and the national education system in an integral manner, placing a special emphasis on the preparation of teachers to direct and facilitate the learning process through the use of new pedagogical practices that consider the variables that recent studies highlight.

Among the most important elements to consider in the evaluation processes, there is motivation, autonomy, social considerations, among others, aimed at ensuring that the learning process has a significant character and can place the student at the center of the education process and not just content.

Likewise, it is necessary to understand that the use of technological tools, such as ICT, automated systems and other forms of online learning, are complementary elements that must be used within a highly motivated academic context, where the student are the main protagonist of the process, from their own motivation and permanent self regulation, for which there are several strategies available in the bibliography, the portfolio would be worth highlighting, for its proven usefulness.

Overcoming the low levels of English proficiency then implies the design of structural responses that can mainstream the entire education system, from basic and secondary education, to create the foundations required by university education systems, therefore working on the diversification of new learning and evaluation strategies is a challenge of the entire education system with an important impact on the potential of national development.

\section{Bibliografía}

Acheson, K. A. (2003). Clinical Supervision and Teacher Development. New York: John Wiley \& Sons,
Inc.

Arias, F. G. (2012). El Proyecto de Investigación. Caracas, Venezuela: Episteme.

Ballestero, C., \& Batista, J. (2007). Evaluación de la enseñanza del inglés con fines específicos en educación superior. Omnia, vol. 13, núm. 1, 105129.

Diaz Mejia, A. (2014). https://repository.icesi.edu. co/biblioteca_digital/bitstream/10906/76938/1/dificultad_aprendizaje_ingles.pd. Recuperado el 02 de 02 de 2020, de https://repository.icesi.edu.co/ biblioteca_digital/bitstream/10906/76938/1/dificultad_aprendizaje_ingles.pd

Education First. (2019). Indice del domínio de Inglés para escuelas. Latino América: EF.

Lunar, L. (2007). El portafolio: estrategia para evaluar la producción escrita en inglés por parte de estudiantes universitarios. Scielo. Núcleo .

Madrid, D. (1997). La evaluación del área curricular de la lengua extranjera. Evaluación Educativa: Teoría, metodología y aplicaciones en áreas de conocimiento,. Granada: Grupo Editorial Universitario.

Martinez, Y., Martinez, O., \& Lopez, M. (Junio de 2013). Research Gate. Recuperado el 02 de Febrero de 2020, de https://www.researchgate.net/ publication/266357715_Metodologia_para_la_ evaluacion_del_aprendizaje_autonomo_del_idioma_Ingles_con_uso_de_las_Tecnologias_de_la_ Informacion_y_las_Comunicaciones_en_los_Centros_de_Autoaprendizaje_y_Servicios_de_Idiomas_Ext

Morales, S., \& Ferreira, A. (2008). LA EFECTIVIDAD DE UN MODELO DE APRENDIZAJE COMBINADO PARA LA ENSEÑANZA DEL INGLÉS1 COMO LENGUA EXTRANJERA: ESTUDIO EMPÍRICO. Revista de Lingüística Teórica y Aplicada , 95-118.

Ruiz Morales, A. (2014). e-EVALUACIÓN DEL APRENDIZAJE: Aproximación conceptual. Revistas Científicas de Educación en Red. Aula Magna 2.0 . 
Veliz Blacio, J. (2020). Innovation strategies in the grammar teaching of English and its effectiveness during the third level educational process. RECIMUNDO, 4(1), 379-389. doi:10.26820/recimundo/4.(1).enero.2020.379-389

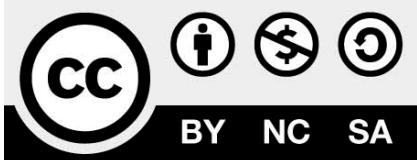

RECONOCIMIENTO-NOCOMERCIAL-COMPARTIRIGUA CC BY-NC-SA

ESTA LICENCIA PERMITE A OTROS ENTREMEZCLAR, AJUSTAR Y CONSTRUIR A PARTIR DE SU OBRA CON FINES NO COMERCIALES, SIEMPRE Y CUANDO LE RECONOZCAN LA AUTORIIA Y SUS NUEVAS CREACIONES ESTÉN BAJO UNA LICENCIA CON LOS MISMOS TÉRMINOS. 